\title{
Cat, Cougar, and Jaguar Spermatogenesis: a Comparative Analysis
}

\author{
Deiler Sampaio Costa ${ }^{1 *}$, Tarcízio Antônio Rêgo Paula ${ }^{2}$ and Sérgio Luiz Pinto da Matta ${ }^{3}$ \\ ${ }^{1}$ Laboratório de Sanidade Animal; Universidade Estadual do Norte Fluminense; Av. Alberto Lamego, 2000; \\ deiler@uenf.br; 28013-600; Campos dos Goytacazes - RJ - Brasil. ${ }^{2}$ Departamento de Veterinária; Universidade \\ Federal de Viçosa ${ }^{3}$ Departamento de Biologia Geral; Universidade Federal de Viçosa; Viçosa - MG - Brasil
}

\begin{abstract}
This work presents a comparative review about the spermatogenic process in cats (Felis domestica), jaguars (Panthera onca) and cougars (Puma concolor), with emphasis on testicular biometry, gonadossomatic index, volumetric proportion of testicular parenchyma components, tubular diameter, seminiferous epithelial height and seminiferous tubule length. It was an approach of the differences among the cell proportions that allowed conclusions about the overall yield of spermatogenic process and Sertoli cell index in three feline species.
\end{abstract}

Key words: Spermatogenesis, felines, testis

\section{INTRODUCTION}

Spermatozoa are produced from stem cells through a cyclic, organized and complex process that takes place within the seminiferous tubules from sexually mature animals, denominated spermatogenesis. It is one of the most productive renewal systems in the animal's body, in which millions of spermatozoa are produced daily from stem spermatogonia.

The spermatogenesis process is divided into three distinct phases: the proliferative phase, in which spermatogonia undergo rapid successive mitotic divisions; the meiotic phase, in which the spermatocytes' genetic material is duplicated, recombined, and segregated; and the differentiation phase, in which haploid cells (spermatids) turn into specialized and structurally equipped cells, in order to fertilize the egg (Costa and Paula, 2003). Although general organization of spermatogenesis is similar in all mammalians, there are particular characteristics among the species in relation to the chronology of the events, the volumetric proportion that is occupied by testicular parenchyma components, the number of spermatogonia generations, cellular population in the seminiferous tubules, daily sperm production, Sertoli cell rate and general spermatogenesis yield (França and Russel, 1998).

Domestic cats (Felis domestica), besides being excellent animals for company, contribute as experimental model in biomedical researches (Godinho, 1999), helping studies of approximately forty physiological anomalies in men, including immunological, toxicological, metabolic and oncologic concerns. Cats are frequently involved in the vanguard of pharmaceutical developments for human use, and they are used in toxicity and security tests for new drugs. This species is extensively used in comparative studies with another feline species (Wildt et al., 1986). All thirty-six wild feline species existent are listed as

* Author for correspondence 
endangered species (CITES, 1997). Such fact reinforces the need for more accurate studies about feline spermatogenesis and reproductive biology. Jaguars (Panthera onca) are the biggest felines found in the Americas, weighing up to $150 \mathrm{Kg}$. Their distribution goes from Mexico to southern Patagonia. Previously they were also found in North America (The World Conservation Union, 1996). This animal lives in a delimited territory, normally from 10 to $40 \mathrm{Km}^{2}$, however, this extension varies with food availability and water presence. The neighbor territories superpose, however male and female meeting happens only in breeding season (Azevedo, 2004). This feline has a compact body with short members; pelage is characterized by the presence of black rosettes around little black spots distributed along the back and the flank. Head, back and feet show little black spots and the pelage background varies from yellow to reddish (The World Conservation Union, 1996). Further, there is a melanin variation, with dominant character, in which the background color is very dark similar to black; however the presence of spots is noted when observed in a very light place. The drawing formed by these spots is unique for each individual, which is very helpful for the animal's identification (Meyer, 1994).

Cougar (Puma concolor) is also known as puma, and both names have been derived from South America native languages. The name Cougar comes from Tupi, and translated as "fake deer", while "Puma" derives from the Peruvian Indian quéchuas and means "magic and powerful animal" (Guião Leite, 2002). They have a wide latitude distribution which includes the most different habitats, occurring from Canada to Chile, including Brazil. Slender and flexible, cougars have strong and muscular members, and the pelvic members are longer than the thoracic ones. This difference is the biggest one among cats, being possibly an adaptation for jumps, as well as the heavy and cylindrical tail, which works as a counterweight (Gonyea, 1976). In tropical lands the pelage is short and ruffled; in extreme latitudes is longer, denser and softer; in a same region the coloration can have a notable variation; there are two basic kinds of coloration: red and gray. The red one has variations in gold and cinnamon that predominate in tropical lands, and the gray goes from silver to bluish and darker animals are found in moist forests at the Northern Coast of the Pacific. The black or melanics appearance was registered at South and Central America, but never at North America (Guião Leite, 2002).

\section{TESTICULAR BIOMETRY AND GONADOSOMATIC INDEX}

During the andrologic evaluation of a male sire, the size of testis is an important parameter, since it gives information about the organ normality and sperm production (Amann, 1970; Amann and Schanbacher, 1983; França and Russell, 1998). For each species, the testis size is determined in response to a variety of factors, besides the primary influence imposed by the body size. However, the number of Sertoli cells, established at the testis development cycle, is the major factor for determination of testis size and sperm production in a given species (Hess et al., 1993; França et al., 1995).

It is usual to observe differences up to $50 \%$ for testis weight among sexually mature animals, even for those species genetically selected, as in bovine (Berndtson et al., 1987). Opposed to what is observed for testis developmental phase (França, 1987) it is not usual to find significant correlation between testis weight and body weight in adult animals (França, 1991).

The theory that better explains the variations in relative testis size in a large number of species is based upon the mating system, i.e., in the sires frequency of coupling (Kenagy and Trombulak, 1986). In this sense, there were two subdivisions: (1) species whose males have low coupling frequency, and (2) species with high coupling frequency. The first group includes species with monogamy behavior, where a male mates one single female, and the extreme polygamy, where one single male copulates all females in a group. In turn, the second group includes species in which several different males copulate with one single female in estrus. Animals from group (1) have testes relatively smaller than those from group (2). This is apparently explained by selection pressure due to the competition for progeny production and to spermatozoa competition inside the female reproductive tract, which occurs in the second group. In these cases, a higher sperm production is required, which confers for these species males with relatively larger testes (Harvey and Harcourt, 1984). Otherwise, males with low coupling frequency usually compete for 
the right to breed, being the most important aspect the behavioral manifestation over the opponents (Short, 1997). In this case, testes are relatively smaller.

According to Kenagy and Trombulak (1986), other factors should also be observed with regard to reproductive behavior. In species in which ovulation is spontaneous, the contest for sperm can be higher than those whose ovulation is induced. Likewise, in species whose females have a more prolonged estrus (several days of duration), usually males have a higher gonadossomatic index when compared with those species whose females present short estrus, $24 \mathrm{~h}$ or less.

Gonadossomatic index (GSI) represents the body mass percentage allocated in testes. It is calculated by dividing the weight of both testes by the body weight, and the result is expressed as percentage.
This index in jaguars is very similar to that observed in cougar and about half the value observed for cats (Table 1). GSI observed in cats confirmed the findings from Kenagy and Troumbulak (1986), which stated that the relative size of testes was inversely proportional to the body size for all mammals, because there was a higher allocation of body mass and energy loss in testicular tissue in small animals.

In cougar and jaguar, the small GSI reflects their reproductive behavior in which a female rarely breeds with more than one male during estrus (Hemker et al., 1992), hence, there is no need for a great investment in testicular mass and consequent sperm production, seen that there will not be a competition among spermatozoa from different males in fertilization of a single female.

Table 1 - Testicular biometry in three feline species

\begin{tabular}{c|c|c|c}
\hline Parameters & Cat $^{\mathbf{1}}$ & Cougar $^{\mathbf{2}}$ & Jaguar $^{\mathbf{3}}$ \\
\hline Body weight $(\mathrm{kg})$ & 3.00 & 45.0 & 78.5 \\
Testis weight (g) & 1.17 & 7.45 & 13.75 \\
Gonadossomatic index (\%) & 0.07 & 0.033 & 0.034 \\
\hline${ }^{1}$ Godinho $(1999),{ }^{2}$ Guião Leite $(2002){ }^{3}$ Azevedo (2004) &
\end{tabular}

\section{MORPHOMETRY OF TESTICULAR PARENCHYMA COMPONENTS}

The volumetric rate of testicular parenchyma components varies greatly among species, mainly the percentage values taken by seminiferous tubules and Leydig cells. This variation is one of the major factors responsible for the difference observed for efficiency in sperm production in several species (Russell et al. 1990; França and Russell, 1998). The tubular compartment is the main component of testes for the greater number of mammals, occupying values between 70 and $90 \%$ of testicular parenchyma in those species (França and Russell, 1998). The percentage occupied by seminiferous tubules in cats, cougar and jaguar (Table 2) is found in that interval, and cats present one of the highest percentages reported for mammals.

In relation to intertubule tissue, the differences noted in Table 2 reinforce the theory that phylogenetics factors are not involved in determination of these values in the different species (Fawcett et al., 1973), since they deal with animals from the same family.
Leydig cells are the major responsible for steroids production. Nevertheless, the reason for the huge variation observed in percentage occupied by these cells in testes is not known yet. Studies correlating structure and function of Leydig cells in several mammal species showed that variations in testosterone secretion result more from the individual capacity of this cell in secreting testosterone than from differences in the total volume of this cell in testes (Ewing et al., 1979).

After sexual maturity, the mean tubular diameter of not-seasonal animals does not suffer significant changes (França and Russell, 1998), and testes size increase after this period is due to the increase of tubule length, not its diameter (França, 1987, Attal and Courot, 1963). According to Paula (1999), several factors contribute for tubular diameter formation, among which can be cited: number of layers from myoid cells in their enveloping membrane; Sertoli and spermatogenic cells size and population; and fluid secretion by Sertoli cells, which determines the cell lumen size. These factors can vary a lot among different mammal species and even among different breeds within a same species and may be the main explanation for 
the large amplitude observed for seminiferous tubular diameter among animals.

When comparisons among species are made, it is important to verify the methodology used, since there are different indexes for tissue shrinkage during the histological procedure, depending on the type of embedding used (França, 1991, Amann, 1981). The values observed in cougar, jaguar and cat were very close and fell within the range considered typical for most amniotes, which was from 180 to $300 \mu \mathrm{m}$ (Roosen-Runge, 1977), since the methodology was the same for the three species. Otherwise, a greater variation was noted as it was observed the seminiferous epithelium height in those species (Table 2). However, values were still pertinent to related for domestic animals, 60 to $100 \mu \mathrm{m}$ (França and Russell, 1998). Although the large variation in this parameters among different species and breed, this did not repeat among the different stages of seminiferous epithelium cycle, in spite of the different cellular associations and the different Sertoli cells volumes in each stage (Wrobel and Schimmel, 1989, Wrobel et al., 1995).

Table 2 - Morphometry of testes parenchyma components in three feline species

\begin{tabular}{l|r|r|r}
\multicolumn{1}{c}{ Parameters } & Cat $^{\mathbf{1}}$ & Cougar $^{2}$ & Jaguar $^{\mathbf{3}}$ \\
\hline Volumetric proportions $(\%)$ & & & \\
Seminiferous tubules & 88.2 & 78.1 & 77.1 \\
Intertubular tissue & 11.8 & 21.9 & 22.9 \\
Leydig cells & 6.0 & 8.2 & 13.0 \\
Stroma & 5.8 & 13.7 & 9.9 \\
Tubular diameter $(\mu \mathrm{m})$ & 223.0 & 227.4 & 257.0 \\
Seminiferous epithelium height $(\mu \mathrm{m})$ & 81.0 & 67.8 & 90.3 \\
Seminiferous tubule length per testes $(\mathrm{m})$ & 23.1 & 136.1 & 167.0 \\
Seminiferous tubule length per gram of testes $(\mathrm{m})$ & 22.8 & 18.3 & 12.2 \\
\hline
\end{tabular}

${ }^{1}$ Godinho (1999), ${ }^{2}$ Guião Leite (2002), ${ }^{3}$ Azevedo (2004)

Considering that the total seminiferous tubule length depends on testes volume, on volumetric proportion of seminiferous tubules and on tubular diameter, it is expected that species that have values near those parameters detain comparable values for the tubular length. However, it is difficult to compare different species, due to the considerable variation in testes weight. In such case, converting the total tubular length per testis in tubular length per gram of testicular parenchyma, it is possible to compare the different species, regardless of animal and testes sizes.

Jaguar presents about $12.2 \mathrm{~m}$ of seminiferous tubule per gram of testis (Table 2), a value that is within the range from 10 to $15 \mathrm{~m} / \mathrm{g}$ described for the majority of domestic animals (França and Russell, 1998), however below that described for cat, $23 \mathrm{~m} / \mathrm{g}$, and for cougar, $18 \mathrm{~m} / \mathrm{g}$. These decreasing values of cat, cougar and jaguar reinforce again the inverse investment in sperm production in relation to body mass.

\section{EFFICIENCY OF SPERMATOGENESIS}

In all species studied until now, only $15 \%$ to $50 \%$ of the theoretically expected spermatozoa are produced (Castro et al., 1997; França and Russell, 1998). This seems to be due to apoptosis that occur during the spermatogenic process, as a homeostatic mechanism utilized to limit germ cells to a number that can be supported by the Sertoli cells available (De Rooij and Janssen, 1987) and for elimination of cells with abnormal or aberrant chromosomes (Roosen-Runge, 1973; Sharpe, 1994). Normally, the higher numeric cellular loss in the majority of mammals occurs at the meiotic phase (Roosen-Runge, 1973). In general, this loss is about $25 \%$, i.e., from each four rounded spermatids expected, only three are actually formed (França and Russell, 1998).

The efficiency of spermatogenic process can be estimated by a very accurate way from numeric indexes among spermatogonia $\mathrm{A}$ and the other germinal cells by transverse section of seminiferous tubules. These indexes allow comparison among different species, and serve as correction factor for the counts obtained through different methodologies and with histology sections with varied thickness (Russell et al., 1990). Usually, there are three indexes used in order to evaluate the different phases of spermatogenesis: spermatogonia mitosis efficiency coefficient (ratio between the number of primary 
spermatocytes in pre-leptotene/leptotene phase and the number of spermatogonia $\mathrm{A}$, in stage 1 tubular morphology); the meiotic index (ratio primary spermatocytes in pachytene : round spermatids); and the general spermatogenesis efficiency (ratio spermatogonia A : round spermatids). The spermatogonial mitosis efficiency coefficient quantifies the degree of cellular loss in spermatogonial or proliferate phase, evaluating the degenerations that occur in cell conversions from spermatogonia $\mathrm{A}_{1}$ until the formation of primary spermatocytes in preleptotene. The meiotic index evaluates the efficiency of both meiotic divisions. In general spermatogenesis efficiency the whole spermatogenic process is investigated. The last one is calculated from the round spermatid population per transverse section of seminiferous tubule. Its reliability as evaluation index of spermatozoa production is based in the fact that losses during spermiogenic process are considered small and insignificant (Amann, 1970; Berndtson, 1977; Johnson, 2000).

In jaguar, about 9.2 primary spermatocytes in preleptotene are produced from each spermatogonium A (Table 3). This yield, although below the amplitude observed for most domestic animals (14.6 to 24.8, França and Russell, 1998), is very similar to the observed for cougar and cat (Table 3). The jaguar meiotic yield was 3.2 (Table 3 ), i.e., there was a loss of only $20 \%$ in the theoretically expected number of round spermatids, which would be four cells. This loss was inferior to the observed in cougar $(25 \%)$ and in cat $(30 \%)$. The spermatogenesis general efficiency in adult jaguar was about 23.4 round spermatids (Table 3 ), value very close to the observed in cougar, above the cat, but very low in relation to the majority of domestic animals (37.4 to 74.2, França and Russell, 1998).

Table 3 - Intrinsic efficiency of spermatogenesis and Sertoli cell index in three different feline species

\begin{tabular}{l|r|r|r}
\multicolumn{1}{c}{ Parameters } & \multicolumn{1}{c}{ Cat $^{\mathbf{1}}$} & \multicolumn{1}{c}{ Cougar $^{\mathbf{2}}$} & \multicolumn{1}{c}{ Jaguar $^{\mathbf{3}}$} \\
\hline Efficiency coefficient of spermatogonial & $7.4 \pm 1.1$ & $7.7 \pm 1.6$ & $9.2 \pm 1.1$ \\
mitosis & $2.8 \pm 0.3$ & $3.0 \pm 1.3$ & $3.2 \pm 0.35$ \\
Meiotic index & $16.3 \pm 3.3$ & $22.7 \pm 3.1$ & $23.36 \pm 2.8$ \\
Spermatogenesis efficiency & $9.8 \pm 0.8$ & $12.5 \pm 1.2$ & $19.2 \pm 4.6$ \\
Sertoli cell index per total germ cells & $5.1 \pm 0.6$ & $7.3 \pm 0.7$ & $11.01 \pm 2.9$ \\
\hline Sertoli cell index per round spermatids &
\end{tabular}

${ }^{1}$ Godinho (1999), ${ }^{2}$ Guião Leite (2002), ${ }^{3}$ Azevedo (2004)

The interactions between Sertoli cell and germ cells are crucial for maintenance of normal sperm production (Griswold, 1995). This cell plays a fundamental role in spermatogenesis morphophysiology and its functions include from physical sustentation of germ cells to the production of numberless paracrine/autocrine factors that modulate sperm production. Thus, the number of Sertoli cells per testis is the main factor in determining sperm production and testis size (França and Russell, 1998). According to these authors, Sertoli cells index varies a lot among species and usually, when the rate Sertoli cells:round spermatids is high, the daily sperm production is also high, because the Sertoli cells ability to support spermatids is highly correlated with the daily sperm production per gram of testis in those species. Each Sertoli cell has a relatively fixed ability to support germ cell in each species and, as its population does not increase after puberty and along the different stages of seminiferous epithelium cycle, this ability only serves as reference to quantify and evaluate functionally the spermatogenic process (Steinberger and Steinberger, 1971).

In jaguar, each Sertoli cell supports approximately 19.2 germ cells (Table 3), which is above the observed for cougar (12.5) and much higher than the observed for cat (9.8). The Sertoli cell index per round spermatids in jaguar is 11.01. This value is close to the average described for domestic species (França and Russell, 1998), and much higher than the described for cougar (7.3) and principally for cat (5.1), suggesting that the daily sperm production in cougar is superior to those of the other two species.

\section{FINAL CONSIDERATIONS}

Cat has the biggest volumetric proportion of seminiferous tubule, the highest seminiferous 
tubule length per gram of testis and double the body mass percentage allocated in testes than the cougar and jaguar. However, as in this species there is a higher loss during spermatogonial mitoses and meiotic division, and Sertoli cells of these animals have a smaller capacity for supporting round spermatids, the process of sperm production of cats are less efficient than cougar and jaguar. Moreover, the spermatogenic process of jaguar is more efficient than cougar.

Although the functional morphology of the spermatogenesis of these three feline species is well studied, there still remains a lot of species of this family that have never been studied and are already endangered even before the basic principles of their reproductive physiology are known.

\section{RESUMO}

O processo espermatogênico do gato doméstico (Felis domestica), da onça-pintada (Panthera onca) e da onça-parda (Puma concolor) são analisados de forma comparativa, dando-se ênfase à biometria testicular, ao índice gonadossomático, à proporção volumétrica dos constituintes do parênquima testicular, ao diâmetro tubular, à altura do epitélio seminífero e ao comprimento dos túbulos seminíferos. Abordam-se ainda as diferenças entres as razões celulares que permitem conclusões sobre o rendimento do processo espermatogênico e índices de células de Sértoli das três espécies.

\section{REFERENCES}

Amann, R. P. and Schanbacher, B. D. (1983), Physiology of male reproduction. J. Anim. Sci. Suppl., 57, 380-403.

Amann, R. P. (1981), A critical review of methods for evaluation of spermatogenesis from seminal characteristics. J. Androl., 2, 37-58.

Amann, R. P. (1970), Sperm production rates. In: Johnson, A. D.; Gomes, W. R. and Vandemark, N.L. (Eds.). The testis. New York: Academic Press. v. 1. pp. 433-482.

Attal, J. and Courot, M. (1963), Développement testiculaire et établissement de la spermatogénèse chez le taureau. Ann Biol. Anim. Bioch. Biophys., 3, 219-241.
Azevedo, M. H. F. (2004), Avaliação morfofuncional do testículo da onça-pintada (Panthera onca) adulta. MS Thesis Universidade Federal de Viçosa, Viçosa, Brazil.

Berndtson, W. E.; Igboeli, G. and Pickett, B. W. (1987), Relationship of absolute number of Sertoli cells to testicular size and spermatogenesis in young beef bulls. J. Anim. Sci., 64, 241-246.

Berndtson, W. E. (1977), Methods for quantifying mammalian spermatogenesis: a review. J. Anim. Sci., 44, 818-883.

Castro, A. C. S.; Berndtson, W. E. and Cardoso, F. M. (1997), Cinética e quantificação da espermatogênese: bases morfológicas e suas aplicações em estudos da reprodução de mamíferos. Rev. Bras. Reprod. Anim., 21, 25-34.

CITES (1997), Convention on International Trade in Endangered Species of Wild Fauna and Flora. In: Conference of the Parties, 10., Harare, Zimbabwe. Proceedings... Harare, Zimbabwe.

Costa, D. S. and Paula, T. A. R. (2003), Espermatogênese em mamíferos. Scientia, 4, 53-72.

De Rooij, D. G. and Janssen, J. M. (1987), Regulation of the density spermatogonia in the seminiferous epithelium of the chinese hamster: I. Undiferentiated spermatogonia. Anat. Rec., 217, 124-130.

Ewing, L. L.; Zirkin, B. B.; Cochran, R. C. et al. (1979), Testosterone secretion by rat, rabbit, guinea pig, dog and hamster testes perfused in vitro: correlation with Leydig cell mass. Endocrinology., 105, 1135-1142.

França, L. R. and Russell, L. D. (1998), The testis of domestic animals. In: Regadera, J. and MartinezGarcia., F. (Eds.). Male reproduction. A multidisciplinary overview. Madrid: Churchill Livingstone. pp. 197-219.

França, L. R. (1991), Análise morfofuncional da espermatogênese de suínos adultos da raça piau. DS Thesis, Universidade Federal de Minas Gerais, Belo Horizonte, Brazil.

França, L. R. (1987), Desenvolvimento testicular de suínos da raça piau, do nascimento aos 12 meses de idade. MS Thesis, Universidade Federal de Minas Gerais, Belo Horizonte, Brazil.

França, L. R.; Ye, S. J.; Ying, L et al. (1995), Morphometry of rat germ cells during spermatogenesis. Anat. Rec., 241, 181-204.

Godinho, C. L. (1999), Análise histométrica do testículo e duração da espermatogênese em gatos (Felis domestica) sexualmente maduros. MS Thesis, Universidade Federal de Minas Gerais, Belo Horizonte, Brazil.

Gonyea, W. J. (1976), Adaptive differences in the body proportions of large felids. Acta. Anat., 96, 81-96.

Guião-Leite, F. L. (2002), Análise morfológica do testículo e do processo espermatogênico da onçaparda (Puma concolor, Wozencraft, 1993) adulta. MS Thesis, Universidade Federal de Viçosa, Viçosa. 
Harvey, P. H. and Harcourt, A. H. (1984), Sperm competition, testes size and breeding systems in primates. In: Smith, R. L. (Ed). Sperm competition and the evolution of animal mating systems. New York: Academic Press. pp. 589-600.

Hemker, T. P.; Lindzey, F. G. and Ackerman, B. B. (1992), Population Characteristics and Movement Patterns of Cougars in Southern Utah. J. Wildlife Manag., 48, 1275-1284.

Hess, R. A.; Schaeffer, D. J.; Eroschenko, V. P. et al. (1993), Adult testicular enlargement induced by neonatal hypothyroidism is accompanied by increased Sertoli cell and germ cell numbers. Endocrinology., 132, 2607-2613.

Kenagy, G. J. and Trombulak, S. C. (1986), Size and function of mammalian testes in relation to body size. J. Mamm., 67, 1-22.

Meyer, J. R. (1994), Black jaguars in Belize. Available in: http://biological-diversity.info/blackjaguar. Access on: 03 Jan. 2004.

Paula, T. A. R. (1999), Avaliação Histológica e Funcional do Testículo de Capivaras Adultas (Hydrochoerus hydrochaeris). DS Thesis, Universidade Federal de Minas Gerais, Belo Horizonte, Brazil.

Roosen-Runge, E. C. (1973), Germinal-cell loss in normal metazoan spermatogenesis. J. Reprod. Fertil., 35, 339-348.

Roosen-Runge, E. C. (1977) The process of spermatogenesis in animals. Cambridge: University Press.

Russell, L. D.; Ettlin, R. A.; Sinha Hikim, E. P. et al. (1990), Histological and histopathological evaluation of the testis. Cache River Press, Clearwater, Florida.

Sharpe, R. M. (1994), Regulation of spermatogenesis. In. Knobil, E.; Neil, J. D. (Eds.). The physiology of reproduction. 2. ed. New York: Raven Press. pp. 1363-1434.
Short, R. V. (1997), The testis: the witness of the mating system, the site of mutation and the engine of desire. Acta Paediatr., 422 : (Suppl.), 3-7.

Steinberger, A. and Steinberger, E. (1971), Replication pattern of Sertoli cells in maturing rat testis in vivo and in organ culture. Biol. Reprod., 4, 84-87.

The World Conservation Union, Jaguar Panthera onca (1996), Available in: http:// lynx.uio.no/catfolk/onça. Access on: 10 Feb. 2004.

Wildt, D. E.; Schiewe, M. C.; Schmidt, P. M. et al. (1986), Developing animal model systems for embryo technologies in rare and endagered wildlife. Theriogenology, 25, 33-51.

Wrobel, K. H.; Reichold, J. and Schimmel, M. (1995), Quantitative morphology of the ovine seminiferous epithelium. Anat. Anz., 177, 19-32.

Wrobel, K. H. and Schimmel, M. (1989), Morphology of the bovine sertoli cell during the spermatogenic cycle. Cell Tissue Res., 257, 93-103.
Received: November 12, 2004; Revised: October 03, 2005; Accepted: July 17, 2006. 